\title{
5 Legal Imagery on the Edge of Symbolism: The Decoration Projects for the Belgian Cour de Cassation ${ }^{1}$
}

\section{STEFAN HUYGEBAERT}

For over half a millennium, courtrooms in the Low Countries have been artistically decorated and, as such, their walls document many transitions in both art and law. This article is concerned with the Belgian fin de siècle around 1900, which constitutes a transitional era in art, with the rise of symbolism, and law, with a legal avant-garde advocating for new law. The focus lies on the Cour de Cassation, Belgium's supreme court, and the decoration projects and plans for its two main rooms inside the enormous Palais de Justice (1866-83) in Brussels, designed by architect Joseph Poelaert. On the left side of the Palais's impressive façade, a projecting part conceals the huge Solemn Room of the Cour de Cassation, used only for its yearly opening session and other ceremonial activities. ${ }^{2}$ A hallway filled with busts of lawyers connects it with the smaller Ordinary Session Room of the Cour, where day-to-day sessions are held. The decoration history of both rooms so far has only been looked at fragmentarily, whilst much can be drawn from the letters kept at the General Archives of Belgium.

This paper questions what courtroom decoration is for, and what it should do. Belgium's fin-de-siècle artistic, political, and legal world presents an interesting case study for two reasons. First, its legal, political, and artistic avant-garde scenes were headed by one and the same group of lawyers; and second, wall decoration was treated in two very different ways, each of which linked its own objective to the decoration type and its use in courtrooms. The more traditional historical-realist wall painting aimed at national education by looking at the past, through (legal) history. Contrarily, symbolist wall painting, such as the works commissioned for the Commercial Court and the Cour d'Assises, also 
housed in the Palais, aimed at a spiritual education or mental edification by depicting an ideal of law and justice.

Scrutinizing the arguments and actors within the debate on the decoration of the two rooms reveals the relationship between artistic and aesthetic change and law's ambition. The argument between historical realism and symbolism is one between old and new, between cautious conservatism and determined modernism, and ultimately between two different views on law's ambition.

Tracing the debate and history of these courtroom decorations tells us about law and its representation as apotropaic and archaic, on the one hand, and affective, on the other hand. The resulting compromise, as can still be seen today, reveals the balanced cautiousness in a country's supreme court, where even absent images and gaping voids tell more than their decision makers intended.

\section{A Call for Symbolist Courtroom Decorations ... and New Law}

When will we see our rooms and vestibules filled with scaffoldings of artists working on the site, like the old masters? ... Nothing arouses artistic temperament more than great works of art. It is the best national education. ${ }^{3}$

It is hard not to recognize the spirit of Edmond Picard (1836-1924) in this call for national education through the decoration of Brussels's Palais de Justice, anonymously published in the Journal des Tribunaux in 1899. Picard's importance for the Belgian legal and artistic world can hardly be overemphasized. He was a leading figure of both the legal and artistic scene in Belgium: he was an avocat and since 1880 a member of the bar of the Cour de Cassation, a senator for the socialist party from 1894, a novelist, and a patron of the arts. Among his numerous initiatives were the founding of both the Journal des Tribunaux and L'Art Moderne in 1881, key periodicals in law and art, respectively. ${ }^{4}$ Both journals had more or less the same group of artistically interested lawyers on their editorial board.

Writing about Belgian fin-de-siècle lawyers such as Picard and Henri Carton de Wiart, Debora Silverman uses the term "juridical modernism," but omits to define this neologism. Bart Coppein's research on Picard's legal thinking is clarifying for the matter - although Picard's views should not be overly generalized. Picard's call for new law was threefold, as suffrage required generalization, justice needed socialization, and the law needed vulgarization. This meant a fight against 
the old threshold system and the general multiple suffrage installed in 1893, in favour of a "one man, one vote" principle. He interpreted the social situation of the working class as a legal issue, arguing that the government should intervene legally in order to defend the weak and emancipate the working class. This would bring change in the paternalistic old order, and, ultimately, "socialize" justice, to use Picard's words. In order to do so, the law had to be explained and spread, and the Journal des Tribunaux was thus both a practitioner's journal and a vulgarizing legal periodical for the broad audience, or this was at least the objective. ${ }^{5}$

What's important to emphasize in this paper is that Picard and his like-minded professional colleagues interpreted the vulgarization of art in the same way. ${ }^{6}$ Although emanating from a bourgeois background themselves, they did not care for art for art's sake. Likewise, these lawyers closely followed the Palais de Justice's construction. In 1911, Picard founded Les Amis du Palais (The friends of the Palace), which promoted the decoration of Belgium's courthouses. One of their main objectives was improving the Palais de Justice's artistic and aesthetic condition. The building's interior decoration had been a concern for many years. ${ }^{7}$ When the 1899 article was published, the Ordinary Session Room of the Cour de Cassation had already been decorated with tapestries, while the decoration of the Solemn Room was still being debated.

The discussions on courtroom decoration uncover an intriguing history of the connection of art and law in a transitional era. With the rise of symbolism, the artistic vision on the decoration of a public building, such as Poelaert's Palais de Justice, shifted. Picard's 1899 article referred with approval to the commissioning of Xavier Mellery (1845-1921) to decorate the Commercial Court inside the Palais. Mellery was one of Belgium's principal symbolist artists and Picard's protégé. Already in 1892, an article in L'Art Moderne called for Mellery to decorate the Palais de Justice, since he alone was seen fit to express the ideal of justice. In the eyes of L'Art Moderne, the artist's task was twofold, as his decorations had to soften, light, and complete the austere, dark, and unfinished Palais, while the artist himself needed to guide the beholder to sublime ideals, which were to be found in the lofty domains of the mind or soul. ${ }^{8}$ Mellery's symbolist allegory for the Commercial Court, entitled The Genius of Trade, was never realized, but its conception was similar to a poster he designed and reused for an international gathering of lawyers in Brussels in 1894. ${ }^{9}$ Both portrayed evocative interacting personifications within an allegory of ideal law. 
A similar kind of allegory was used by Jean Delville (1867-1953), another Belgian symbolist heavy-weight, in his decorations for the Cour d'Assises in Poelaert's building. In line with Delville's idealist principles, his decorative paintings featured a double juxtaposition. A terrifying image of Moses stopping two men from killing each other ("Thou shalt not kill") hung opposite an image of Christ visiting convicted felons. Equally, Old Law was evoked by means of an enthroned and hooded man torturing a convict, in contrast to New Law, a modern magistrate with the face of a former minister of justice, Jules Le Jeune (1828-1911), accompanied by a personification of science. In the central allegory, titled Ideal Justice, on the wall opposite the judges, a winged Justice was flanked by Compassion and the Law. ${ }^{10}$

These kind of decorations were, according to the Journal des Tribunaux, far from redundant. On the contrary, they served a specific purpose:

The décor acts so profoundly upon us. There is a mysterious link between the minds and their familiar retreat. What comes about in a beautiful and complete environment comes out beautiful and complete. And for those who desire for all things the correction of a perfect justice, they must start by educating their mind. The décor in which they will live is the first of these duties and worries. By persistently harmonizing the very environment and themselves, making it more beautiful and perfect, they themselves will come out more noble and just. ${ }^{11}$

By means of this call for decorative art to serve didactic ends, the author of the 1899 article was not proposing an entirely innovative idea. Half a millennium earlier, indeed, in a description of local customary law in a small Dutch town called Den Briel, Jan Matthijssen wrote how courtrooms should be decorated. "The courtroom will be made clean inside and filled with paintings and written with good old wise words, from which one can acquire wisdom and cleverness, as one says: to see is to think."12 Thus, the goal of these two types of courtroom decoration, paintings and words, was to provoke wisdom and insight by means of visual confrontation. The citation refers to late-medieval and early-modern use of exempla justitiae, artworks commissioned by aldermen and magistrates as courtroom decorations. In 1525, for example, Jan Provoost (c. 1465-1529) painted a Last Judgment, one of the key subject matters of such exempla, for the courtroom in the town hall of Bruges. The accompanying Renaissance frame by Lanceloot Blondeel (1498-1561) features Latin biblical quotations, such as "Videte quid 
faciatis: non enim hominis exercetis judicium, sed domini" ("Consider carefully what you do, because you are not judging for mere mortals but for the Lord," 2 Chronicles 19:6).

The two types of courtroom decoration mentioned by Matthijssen help distinguish between the two sides of the debate over the Palais de Justice's decoration. In her extensive work on Belgian wall painting, Judith Ogonovszky-Steffens emphasizes an opposition within the history of wall painting as an art form in the fin de siècle. During the last decades of the nineteenth century, historical wall painting depicting episodes from national history, collided with a more recent kind of idealist wall painting, referring to symbolist principles about a superior world and the essence of human being. ${ }^{13}$ The first type includes portraits of great men and realist paintings depicting historical events, offering choice selections from national legal history. This is what Valérie Hayaert and Antoine Garapon, in their analysis of the fin-de-siècle courtroom decorations in Besançon, describe as making history into a véhicule, a vector by means of which civic virtues are exalted. ${ }^{14}$ Historical wall painting could be interpreted as the descendants of Matthijssen's paintings or "portraiture" in old Dutch. Within the dichotomic scheme, Matthijssen's "old wise words" become synonyms for the idealists' allegories about law and justice, which sought to evoke universal, everlasting principles, the symbolist wall paintings as OgonovskySteffens's second type. For example, Mellery's 1894 poster even literally included "wise words," maxims such as "Brotherhood is the basis of law" and "Without goodness, Justice fails in her task." In 1907, Carton de Wiart, the president of the Young Bar Association suggested that words, maxims, verse and prose - dating back as far as Solomon - should be written on the interior walls of the Palais de Justice. These words expressed ideals which were meant to inspire the upholders of justice. ${ }^{15}$ The dichotomy can be synthesized as follows:

\begin{tabular}{lll}
\hline $\begin{array}{l}\text { Matthijsen's instructions } \\
\text { (1405) }\end{array}$ & Portraits & Good old wise words \\
\hline $\begin{array}{l}\text { Type of wall painting } \\
\begin{array}{l}\text { Type of representation } \\
\text { Typical subject matter }\end{array}\end{array}$ & $\begin{array}{l}\text { Historical realist } \\
\text { Portraits and history scenes } \\
\text { Local (legal) history, } \\
\text { in casu ancient } \\
\text { lawyers and courts }\end{array}$ & $\begin{array}{l}\text { Symbolist } \\
\text { Allegories } \\
\text { Personifications; heroes and } \\
\text { stories drawn from bibli- } \\
\text { cal, mythological, literary, } \\
\text { and historical sources }\end{array}$ \\
$\begin{array}{l}\text { Objective as interpreted by } \\
\text { Picard's legal avant-garde }\end{array}$ & National education & Edification of the mind \\
\hline
\end{tabular}




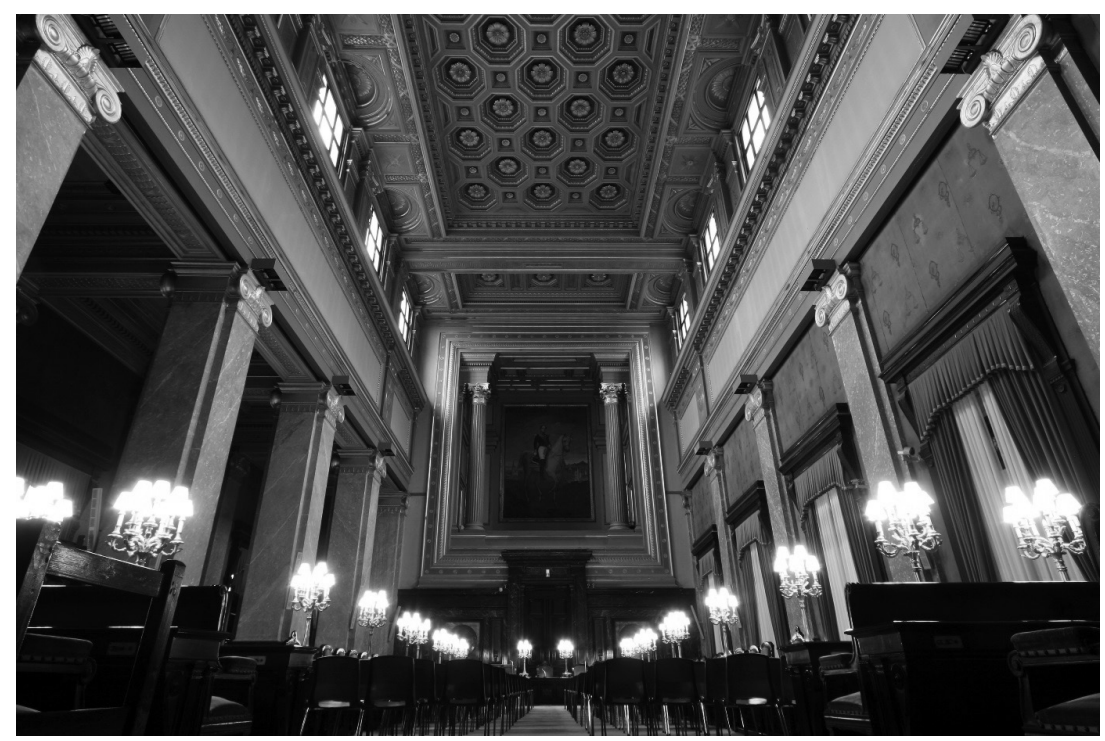

Figure 5.1 The Solemn Room of the Cour de Cassation, with the equestrian portrait of Leopold I by Eugène Van Mierlo, installed c. 1954. (C) Tchorski.

\section{The Decoration of the Solemn Room of the Cour de Cassation}

Each side of the Solemn Room features an empty one-and-a-half-metrehigh frieze, divided into three - one long piece measuring thirteen metres flanked by two shorter fragments of three metres. A huge frame of over 30 square metres hangs at both ends of the room. These frames and friezes had remained empty since the Palais's inauguration on 15 October 1883.

Six years later, in 1899, the first recorded proposal to fill these voids came from Alfred Cluysenaar (1837-1902), a late Romantic painter and decorative artist. In his letter to Jean-Baptiste Rousseau (1829-91), the director-general of the Belgian government's fine arts department, Cluysenaar expressed his preference for a uniformly gold-coloured background, in keeping with the surrounding marble. The most appropriate subject matter, according to the artist, was to be found in the Cour de Cassation's history. Cluysenaar was an established history painter, who could rely on a career of historical wall paintings of the official, academic kind. ${ }^{16}$ 
Cluysenaar, however, was an artist, not a legal historian. His choice of dates and even words makes it possible to reconstruct his sources. For the larger part of his proposal, Cluysenaar drew on a book from 1866 about the Cour de Cassation written by Camille Scheyven (1838-1913), who later became first president of that court. Scheyven wrote that the Cour de Cassation "is also and foremost, on our soil, the successor in direct line of the Great Council of Malines." The way Scheyven had it, his contemporaries could learn from the intellect of the medieval and early-modern Malines lawyers, as well as from their interpretation of organizational and procedural laws, since "the customs and the character endure the ages and outlive their laws." ${ }^{\prime 17}$

On the basis of Scheyven's historical overview, Cluysenaar picked and listed some of the crucial events from the Great Council's history as well as from the history of those courts that were interpreted as its successors. He suggested to fill the friezes with scenes of the foundation of the court (Burgundian era), an ordinance by Emperor Charles V (Habsburg era), a French revolutionary ordinance from 1795 (French era), and the opening session of the actual Cour de Cassation on 15 August 1832 (Belgian era). As for this event, Cluysenaar repeated Scheyven's comment that, in 1832, the Cour de Cassation's judges wore black gowns. For the sake of the decorative ensemble, however, he proposed to dress them in red. This tiny adjustment demonstrates how historical realism in wall painting, formerly characterized by an almost archival attention to detail and authenticity, had started to give way to more personal aesthetic considerations - for art's sake - marking its transformation into an allegorical or symbolist kind of wall painting.

Cluysenaar's suggestion for the two large frames on each side of the courtroom are equally revealing. As an alternative to more historical scenes, Cluysenaar advanced the use of painted allegories of universal, eternal principles. "They should, according to me, represent general ideas of Justice ... Equality of Justice for all ... Justice is limited in its action ... Justice is free of charge."18 Cluysenaar, however, did not succeed in defining the actual content of these principles. He merely stated that they should be fitting "to the level of the destination." Despite this vagueness, all those involved in the decision-making process agreed that the decorations had to be in line with the solemn and lofty character of the court.

One important voice was that of the president of the Royal Committee for Monuments, François Wellens (1812-97), an engineer and the administrative head of the Palais de Justice's construction. Already in 
1881 he had written that the Palais's architect had provided numerous spaces in the interior "where painting and sculpture one day will be called to reproduce the memory of the country's illustrious legislators and lawyers, who did their country honour, as well as those historical events that have strongly contributed to assure Belgium's high rank amongst the civilized nations." ${ }^{19}$ This somewhat dated view in favour of historical realism and wall painting would prove incompatible with most of the commissioned artists' ideas and designs for both rooms of the Cour de Cassation. For instance, in contrast to Cluysenaar's proposals for the Solemn Room, Wellens had in mind a historical scene in which Leopold I, Belgium's first king, approved the plans for the Palais de Justice. ${ }^{20}$ Whilst financial issues were still being debated, the inspector for fine arts, Émile Leclercq (1827-1907), suggested that Cluysenaar be allowed to start the large painting, but employing Wellens's preferred subject matter, and so avoiding the apparently problematic symbolist aspects of the artist's initial design.

However, even this compromise did not pass. In 1908, some twenty years after Cluysenaar's letter, Émile Fabry (1865-1966), one of Belgium's leading symbolist painters, presented a new proposal to decorate the Cour de Cassation's Solemn Room. Fabry had demonstrated a clear interest in the worlds of dreams, Platonic ideas, and Nietzschean philosophy, creating allegories whose heroes were drawn from Greek mythology, the Bible, or Wagnerian operas. By the time he started the Cour de Cassation project, Fabry had obtained the commission to decorate the staircases of the Monnaie opera house, a highly prestigious job. He worked on the Monnaie commission in different stages until 1933, and painted symbolist compositions such The Poet Adoring Beauty. Fabry's plans for the Cour de Cassation shared much of the hermeneutist character and mythological references of this work. Key figures for his Cassation projects were biblical and mythical: Moses, Christ, and Prometheus, each of whom had pleaded for the destiny of man before their respective gods, and had fought against some kind of repression. ${ }^{21}$

Art critic Edmond Louis de Taeye wrote in 1911 that Fabry's work "talks to the soul, makes you think and realizes, as such, one of the major goals of great art." ${ }^{22}$ It is not surprising that Edmond Picard and his art-minded colleagues of Les Amis du Palais welcomed Fabry's initial project. These were more or less the same people who authored the 1892 and 1899 articles, asking for art which addressed and educated the mind and soul. In 1912, Les Amis du Palais even stated that it was one of their main goals to have Fabry's projects realized. ${ }^{23}$ 
In his earliest known version, dating from 1908, Fabry wished to fill the two large frames with the expulsion of Adam and Eve from paradise and Christ's crucifixion. This opposition seemed fitting for a Cour de Cassation; the latter episode quashed the first, much like the councillors' decisions quashed previous judgments. "God has expelled Adam and Eve from earthly paradise, after their offence, but he has reformed his first judgment by means of the baptism [of Christ] and has quashed his verdict by means of the death of Jesus Christ." ${ }^{\prime 2}$ The opposition is also analogous with the Lutheran understanding of the Old and New Testament and the evangelical theme known as Law and Gospel, or Law and Grace. Painters such as Lucas Cranach the Elder (1472-1553) had used the biblical scenes Fabry intended to depict, within didactic evangelical images. A similar opposition between Old and New Testament Gods, between justice and mercy, would be used by Jean Delville in his decorations for the Cour d'Assises. ${ }^{25}$

Originally, Fabry considered having the long friezes feature a chained Prometheus, one of the symbolists' favourite heroes. By 1913, the fire thief had disappeared from the projects and the Fall of man and the baptism had been added. The room would feature a double juxtaposition, with the Fall opposite the crucifixion, and the expulsion from Paradise opposite Christ's baptism. However, after having shown his project to Les Amis du Palais in 1913, Fabry lost their support.

The subject which he chose did not please all, and specifically the occupants - the judges and members of the Public Ministry of Cassation did not show themselves enthusiastic about these decorations. However, it is recognized by all that the panel which surmounts the entrance door of this sumptuous room asks for something else than the drapery that is currently hanging there. Some suggest that an art work of great allure should be hung there, representing our great king Leopold II. It is certain that, if a great work of art would feature this figure, it would be admirably placed in the sumptuous frame of the Cour de Cassation. ${ }^{26}$

At a time when decoration commissions for public buildings in Brussels welcomed symbolist, allegorical wall paintings, the decision makers opted for a far more traditional subject matter for the Cour de Cassation. Despite Fabry's alternative and revised projects from 1925 (in which a chained Prometheus reappeared, in combination with the Fall of man) and 1941, and despite the approval of Procurator General Collard, Fabry's plans were never executed, due to the lack of 
sufficient budget. ${ }^{27}$ Eventually, in the 1950s, an equestrian portrait of Leopold I by Eugène Van Mierlo (1880-1972) was put in the frame of honour above the heads of the country's highest judges. Several Belgian buildings, including the Antwerp and Tournai cathedrals and the Liège perron, are featured within a fictional background. Opposite Leopold, on the other end of the room, a standing portrait of Philip the Good by the same painter fills the frame. In a piece of teleological and patriotic history writing bridging four centuries, the late-medieval conditor Belgii, who brought most of the "Belgian" territories under one and the same rule for the first time, almost looks into the eyes of the first king of Belgium.

The friezes, however, remain empty, and their remaining voids remind us of the difficulties of courtroom decoration in general and the Belgian fin de siècle and Cour de Cassation in particular. Here is a Solemn Room of which newspapers such as L'Indépendance Belge emphasized the apotropaic and archaic nature, and whose decoration's function they compared to the military's gaudery: to arouse an irrational fear..$^{28}$ Indeed, the only consensus that can be found in the debates is one about the lofty nature of the Cour. The eventual compromise consists of two half-hearted historical reconstructions nothing close to the symbolist allegories of law's ideals, advocated for by Picard's avant-garde circle. Quite the contrary, in their emptiness the 1950s portraits of Leopold and Philip hardly seem to fill their frame's void, but remind us only of a lack of judgment and decision in favour of compromise.

\section{The Decoration of the Cour de Cassation's Ordinary Session Room}

Ironically, the Cour de Cassation's Ordinary Session Room, used on a day-to-day basis, stimulated far more sumptuous and prestigious projects. Braquenié et Cie, a French company with a branch in Malines, which produced tapestries for European royal courts including Napoleon III, proposed a series of tapestries to decorate the blank spaces of wall between the windows, and at both ends of the room. ${ }^{29}$ Due to their high production costs, tapestries traditionally had a higher prestige than murals. Many of the original "cartoons," as tapestry designs are called, were drawn by Willem Geets (1838-1919). Among his commissions were the tapestries for Brussels's town hall and the senate's smoking room, which featured historical scenes such as Philip the Good Receives the Eastern Ambassadors. For the Cour de 


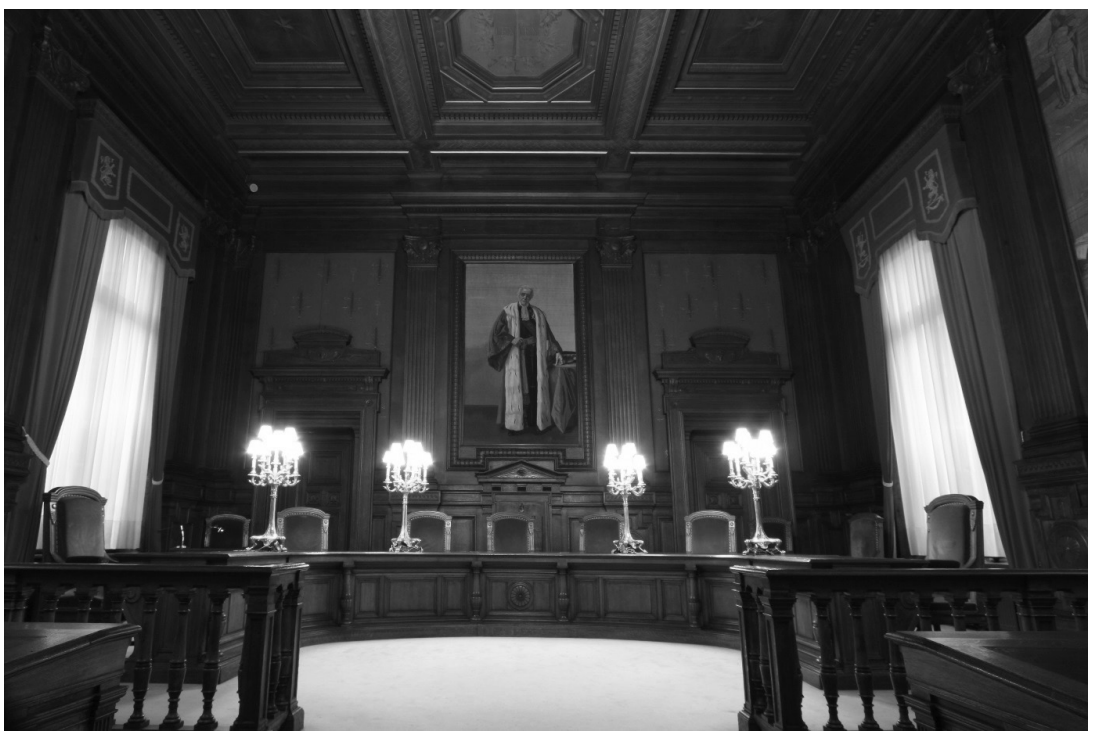

Figure 5.2 The Ordinary Session Room of the Cour de Cassation, with the central portrait tapestry of Eugène de Gerlache by Willem Geets, installed in 1895. (C) Tchorski.

Cassation, as opposed to their earlier historical material, the firm proposed allegorical tapestries, including Justice, Law, Jurisprudence, Equity, Eloquence, Roman Law, and Customary Law. ${ }^{30}$

The Administration for Fine Arts seemed favourably disposed towards Geets's decoration project, on the condition that the artist made some changes and submitted new cartoons. Following the adjustments to the designs for The Law and Force - a new theme - the minister in charge approved the changes, as did the members of the Cour de Cassation. Their president, Guillaume De Longé (1815-90), had been member of the jury deciding on the Palais de Justice's construction back in 1860 . He wrote that the allegorical subjects were perfectly appropriate for the building's decoration, but that the court was not competent to decide on aspects "that [are] a matter of art and tradition." ${ }^{31}$ As to the suitability of allegorical treatments, the court stated, "It [the Cour de Cassation] considers allegories to be more decorative and thinks that otherwise a modern portrait would be surprising amidst ancient portraits." ${ }^{\prime 32}$ 
François Wellens's Royal Committee for Monuments reacted far more negatively:

Although the artist's [Geets] decoration program seems to us acceptable in principle, the Committee would prefer that the subject matter of the decorations would be somehow different than purely allegorical. We then consider that these subjects have not been treated with the necessary severity, given the special destination of this decoration ... [I]t would be far more preferable to replace these allegorical subjects proposed by the artist with portraits of illustrious lawyers. ${ }^{33}$

At once, the committee drew up a list of lawyers from "Belgian" legal history, including their historical merits. All the selected lawyers had already been part of a larger list drafted by Jacques Britz (1806-67). A lawyer and legal historian, in 1847 Britz composed a list of men whom he thought had earned a portrait, bust, or statue. The purpose of this kind of glorification of legal scientists was, according to Britz, to "make science itself progress, to arouse sentiments of nationality, to conserve glorious traditions and to satisfy a legitimate desire of the country." ${ }^{\prime \prime 4}$ In addition, the modern portraits had to link Belgium's past with its present, and thus they explain what national education through historical wall painting would aim at.

Earlier decorations in the Palais de Justice were clearly in line with this particular kind of "national education" pantheon. In 1885, when the walls of both rooms of the Cour de Cassation were still vacant, there were already reports of an "avalanche of busts" in the Palais. ${ }^{35}$ Wellens's committee clearly wanted to continue this tradition in the Ordinary Session Room, at the expense of the allegorical designs. They argued that tapestries in general (and with them, Geets's allegorical program) would not fit the walls of the room, and that busts would be preferable. However, after a try-out with existing busts, the idea was abandoned. ${ }^{36}$

Despite the approval of the Cour de Cassation's president for Geets's tapestry program, and much to the surprise of the Fine Arts administration, in 1893 Geets was commissioned to design five portrait tapestries. The earliest was of fifteenth-century lawyer Filips Wielant, who was a councillor at the Parlement de Malines immediately after its founding in 1473 and served the courts of Mary of Burgundy, Maximilian of Austria, and Philip the Handsome. Geets included these three sovereigns in the tapestry's background. Wielant also wrote vernacular publications on civil law (Practyke civile) and criminal law (Practycke criminele), 
which gained international fame due to Latin translations by Joos de Damhouder. ${ }^{37}$ Damhouder (1507-81) also got his woven portrait in the Cour de Cassation. Most probably, Geets referred to Damhouder's writings, Praxis rerum civilium and Praxis rerum criminalium by means of the books featured next to the lawyer, dressed in a black gown and standing in front of a wall with wainscoting and gold leather. ${ }^{38}$ The third tapestry shows a baroque interior with Pieter Stockmans (1608-71), a clergyman who lectured as a humanist at the collegium trilingue and was rector of Leuven University. The committee eventually opted for Eugène Defacqz (1797-1871) for the fourth tapestry. Defacqz's portrait, too, had sculptural precedents within the building. It was preceded by two busts, both by Charles Van Oemberg. One showed Defacqz in his civil clothes as a politician and co-founder of the Belgian liberal party (1846); the other was meant for the Palais de Justice and showed him as a magistrate and president of the Cour de Cassation. A legal historian, Defacqz had written - among others topics - about the Council of Malines in his Ancient droit belgique (1873). ${ }^{39}$

What remained was the central and most honourable space, directly above the seat of the first president of the Cour de Cassation. Originally, Wellens's committee preferred a portrait of Leopold I signing the organic law concerning the legal order, one year after his inauguration as Belgian king. Since plans existed to include Leopold in the Solemn Room, the committee eventually proposed Étienne-Constantin de Gerlache (1785-1871). De Gerlache was Belgium's man of firsts. He was the first president of the country's Constitutional Assembly, the Chamber of Representatives, and the Cour de Cassation. Despite his advocacy for a strict separation of the trias politica in his days as a Belgian revolutionary, de Gerlache came to symbolize the politically influenced appointments of the early Belgian years. He became first president of the Cour de Cassation without any magistracy experience, thanks to his Catholic political connections. ${ }^{40}$ No doubt, in a country where the political landscape for over half a century was dominated by the quarrel between liberals and Catholics, de Gerlache's portrait was thought to balance that of Defacqz.

From the many letters between the different administrations, the Cour de Cassation, and the artist, it is hard to find a real argument in favour of the portraits. However, some of the arguments against Geets's allegorical designs could just as well be read as a disapproval of symbolist art and wall painting. A letter to Bracquenié asked him to exclude "the nudity and small child figures" and rejected his "black 
backgrounds, in the manner of Pompeian decorations." ${ }^{\prime 1}$ Symbolist art frequently featured nude, idealized, athletic bodies - often of children and ephebes - in front of decontextualized monochrome backgrounds. The decorations by Albert Ciamberlani (1864-1956) in the Court of Appeal in the Palais de Justice, started in 1902, were covered up immediately after their inauguration in 1957, due to the abundant presence of nudes. Mellery, too, was associated with a certain degree of eroticism evoked by nude bodies, and perhaps this was the reason his design for the Commercial Court, featuring a naked breastfeeding woman, was never realized..$^{42}$

Thus, the final execution of the Ordinary Session Room's decoration confirms the opinion that respect for a country's supreme court is better found in its history than in wise words or symbolic lessons. Here, the interpretation of the Cour de Cassation's sumptuousness dominated the committee's aesthetic judgment, which was essentially iconoclastic, as in their view representing or allegorizing the law on such a level as the supreme court was unfit and impossible, unless by means of history. Contradictorily, in their determined demand for historical portraits, the committee unconventionally quashed the judgment of those at the top of the judicial hierarchy, a hierarchy they were so anxiously protecting.

\section{Conclusion}

The two massive portraits of the first "Belgian" ruler (Philip the Good) and the first Belgian king in the Solemn Room of the Cour de Cassation are the result of a non-judgment, a weak compromise. The five woven portraits drawn from the country's pantheon of illustrious lawyers in the Cassation's Ordinary Session Room originated in a firm belief in authority through hierarchy and history. In both cases, litigants, lawyers, magistrates, and visitors are confronted with a distant past. This distance is no different than the one criticized by Robert Jacob in his survey on legal imagery. According to Jacob, legal imagery in general and courtroom decorations in particular feature something of a downward evolution. First, the great and gruesome medieval exempla justitae depict good or bad judgments and legal practices using biblical episodes, antique stories, myths, and local legends, in a time when justice was executed in the centre of society. The distance, alienation if you will, started with the allegorization of Justice into a single figure, that of the lady with the sword and scales, and met its climax with the apotropaic temples of the law constructed in the nineteenth and twentieth 
centuries - perhaps most of all in the world's biggest building at the time, Brussels's Palais de Justice. ${ }^{43}$

To many, the men featured in the Cour de Cassation decorations were - and still are - as anonymous as the many products of the period's statuomania, and thus their project of national education through art missed its goal. For how was one to draw lessons from a portrait of a long-forgotten and de facto anonymous man $?^{44}$ Arguably, the only lesson would be one in the history of design. In his backgrounds Geets included a textbook overview of historical wall decorations, from the medieval tapestries behind Wielant, past Damhouder's sixteenthcentury Spanish gold leather and Stockman's heavy baroque curtain, to Defacqz's early-nineteenth-century wall painting. The same could be said about the lawyers' uniforms. It is not legal history but aesthetic history that is most clearly articulated here.

However, in this light, symbolist allegories could hardly be seen as a better alternative, given their equally illegible nature - despite Picard's wish for the vulgarization of art. It is therefore reasonable to state that the via media was reached in the tapestry of Étienne de Gerlache, of which a review quoted by Journal des Tribunaux wrote: "One cannot help but feel a kind of respect in the presence of the stately appearance of this representative of law and order. The sumptuous tone of the long red gown bordered with ermine is of a most fruitful decorative effect, and forms, with the colour of the oak wainscoting, an opulent harmony." 45

This is where the lesson in the history of design stops. The background is largely monochrome and gold, against which the icon-like portrait looks decontextualized and sacral - the intended effect of many symbolist backgrounds. The judge's gown does what it is made for: it is sumptuous, expensive looking, and marks the "representative of law and order." At the same time, authority for Belgium's supreme court is found in history, its own history, with a depiction of its first president, its founding father. Even when national education was lacking and the visitor or beholder is unaware of de Gerlache's identity and history, an edification of the mind is achieved, one that asks for respect for the court's authority, and the legal system's hierarchy. The gold and gown of man and building form "an opulent harmony": they are eclectic, archaic, and apotropaic. Time and again, journalists from the liberal newspaper L'Indépendance Belge characterized the Solemn Room, too, as excessive, lavish, "gilded, salmoned, chocolated and marbled," "naturally lacking this sober and adequate simplicity needed for a 
courtroom,"46 a courtroom which "create[s] a certain superstitious fear." ${ }^{47}$ Moreover, its ceremonies were "fustian we would way, if we dared to," and the Cour de Cassation was a place "where modernism has no hold over respectable and conventional traditions." ${ }^{\prime 4}$

In this court, the ideals of one and the same group of lawyers, headed by Picard, advocating for symbolist wall paintings and supporting the idea of new law and progressive political changes, in one and the same avant-garde quest, met resistance. Thus, most of the walls of the Cour de Cassation's Solemn Room remained empty, and our story becomes one of visual images that never were, in a time of important legal debate and transition. However, in their absence - an absence revealed through the study of archival sources - these non-images remain important signposts of conservatism.

Although the Solemn Room was unknown to many citizens, L'Indépendance Belge thought people should know of it, since it demonstrates the country's degree of civilization. Here again, national education of the people came to the foreground. Likewise, as in the case of de Gerlache's portrait in the Ordinary Session Room, the judges themselves were enough of a spectacle, a decoration. ${ }^{49}$ In the absence of actual paintings, these old men literally became a tableau, an image, a history painting: "As we know, the members of the Cour de Cassation are, for the most part, men of very advanced seniority, whose spry old age and venerable appearance add to the prestige of the assembly. The spectacle for the eyes is not to be despised ... [Like a] tableau of a past age, which would tease the pencil of a painter of ... historical reconstructions." ${ }^{\prime 50}$

\section{NOTES}

1 This contribution is the shortened, adapted, and translated version of a part of the book chapter by Stefan Huygebaert, "'Le décor au milieu duquel ils vivront': Beeldhouwkunst en decoratie in het Justitiepaleis," in Genius, Grandeur en Gêne. Het Fin de Siècle rond het Justitiepaleis te Brussel en de controversiële figuur van Edmond Picard, ed. Willy Van Eeckhoutte and Bruno Maes (Gent: Knops, 2014), 117-83. I owe my gratitude to Dirk Heirbaut, Georges Martyn, Bruno De Wever, Sebastiaan Vandenbogaerde, Nathalie Tousignant, Matthias Van der Haegen, Judit Beke-Martos, Jana Wijnsouw, Desmond Manderson, and Jan Caudron. This article was realized with the support of the IAP "Justice \& Populations" (PVII/22), 
Interuniversity Attraction Poles Programme - Belgian Science Policy; and the Research Foundation - Flanders (FWO).

2 On the Cour de Cassation see Georges Martyn, "Belgium, the Netherlands and Luxembourg since 1800," in European Supreme Courts: A Portrait through History, ed. R.C. Remco Van Rhee and Alain Wijffels (London: UK Third Millennium Publishing, 2013), 218-27. Françoise Muller, La cour de cassation belge à l'aune des rapports entre pouvoirs (Bruges: La Charte, 2011).

3 "La décoration du Palais de Justice," Journal des Tribunaux, 1899: 142. Quotes are translated from French by myself unless stated otherwise.

4 On Picard and the other artistically interested lawyers, see Jane Block, ed., Belgium, The Golden Decades 1880-1914 (New York: Peter Lang, 1997); Bart Coppein, Dromen van een nieuwe samenleving: Intellectuele biografie van Edmond Picard (Brussels: Larcier, 2011); Paul Aron and Cécile VanderpelenDiagre, Edmond Picard (1836-1924): Un bourgeois socialiste Belge à la fin du dix-neuvième siècle. Essai d'Histoire Culturelle (Brussels: Musées Royaux des Beaux-Arts de Belgique, 2013) ; Debora Silverman, “'Modernité sans Frontières': Culture, Politics, and the Boundaries of the Avant-Garde in King Leopold's Belgium, 1885-1910,' American Imago 68, no. 4 (2011): 707-97.

5 Silverman, "'Modernité sans Frontières,'” 709.

6 Stefan Huygebaert and Sebastiaan Vandenbogaerde, "Êtes-vous Justice, Minerve ou Thémis? Een tijdschriftlogo als numen mixtum en symptoom van de versmelting van kunst en recht in het Belgische fin de siècle," Pro Memorie. Bijdragen tot de rechtsgeschiedenis der Nederlanden 16, no. 2 (2014): 244-58.

7 "Constitution des Amis du Palais," Journal des Tribunaux, 1911: 1142 ; “Les Amis du Palais," ibid., 1275.

8 "La décoration du Palais de Justice," L'Art Moderne, 1892: 401-2.

9 Anne-Marie Geerinck, "De Decoratie van het Justitiepaleis te Brussel," in Poelaert en zijn Tijd, ed. Richard Vandendaele (Brussels: Gemeentekrediet, 1980), 300-2.

10 Emilie Berger, "Jean Delville et l'enjeu du 'Monumental,'" in Jean Delville (1867-1953) Maître de l'Idéal, ed. Denis Laoureux (Paris: Somogy, 2014), 106-14.

11 "La décoration du Palais de Justice," Journal des Tribunaux, 1899: 142.

12 Quote translated from Middle Dutch. Jan Matthijsen, Het Rechtsboek Van Den Briel, Beschreven in Vijf Tractaten, ed. J.A. Fruin, and M.S. Pols ('s-Gravenshage: Nijhoff, 1880). Georges Martyn, “Inspiring Images for Judges. Late Medieval Court Room Decorations in the Southern Netherlands," in The Iconology of Law and Order (Legal and Cosmic), ed. 
Anna Kérchy, György E. Szönyi, and Attila Kiss (Szeged: JATE Press, 2012), 37-49. Stefan Huygebaert, Georges Martyn, Vanessa Paumen, and Tine van Poucke, The Art of Law: Three Centuries of Justice Depicted, (Tielt: Lannoo, 2016).

13 Judith Ogonovsky-Steffens, La peinture monumentale d'histoire dans les édifices civils (Brussels: Académie Royale de Belgique, 1999), 354-7. Judith Ogonovszky-Steffens, "Un idéal de mur," in Splendeurs de l'Idéal: Rops, Khnopff, Delville et leur temps, ed. Michel Draguet (Gent: Snoeck-Ducaju, 1996), 179-97.

14 Valérie Hayaert and Antoine Garapon, Allégories de Justice: La grand'chambre du Parlement de Flandre (Abbeville: F. Paillart, 2014), 100.

15 Henri Carton de Wiart, "Décorum judiciaire," Journal des Tribunaux, 1907: 404-5.

16 Judith Ogonovszky-Steffens, "Cluysenaar, Alfred," in Nouvelle biographie nationale (Brussels: Académie Royale de Belgique, 1999), 58-60.

Ogonovszky-Steffens, La peinture monumentale, 325-51; General Archives of Belgium (GAB), Fine Arts Records (FAR), no. 368.

17 Camille Scheyven, Traité pratique des pourvois en cassation, de l'organisation et des attributions diverses de la cour suprême (Brussels: Bruylant-Christophe \& compagnie, 1866), 6-7, 23.

18GAB,FAR,no.368.

19FrançoisWellens, Le nouveau Palais de Justice (Brussels: H. Leys, 1881), 19.

$20 \mathrm{GAB}, \mathrm{FAR}$, no. 368.

21 Jacqueline Guisset, Emile Fabry (1865-1966) (Brussels: Fonds du patrimoine de Woluwe-Saint-Pierre, 2000), 9, 11, 32, 81, 108-10.

22 Ibid.

23 "Les Amis du Palais. Assemblée générale de 18 mai 1912," Journal des Tribunaux, 1912: 635; “Les Amis du Palais," ibid., 1197 ; “Les Amis du Palais," Journal des Tribunaux, 1913: 811.

24 "Les Amis du Palais. Un projet de décoration de la Salle des Séances Solennelles de la Cour de Cassation," Journal des Tribunaux, 1913, 323.

25 Bonnie J. Noble, "'A Work in Which the Angels Are Wont to Rejoice': Lucas Cranach's 'Schneeberg Altarpiece,'"' The Sixteenth Century Journal 34, no. 4 (2003): 1018-25.

26 “Les Amis du Palais," Journal des Tribunaux, 1913: 1292.

27 Guisset, Emile Fabry, 83-9.

28 L'Indépendance Belge, 11 October 1910, 3.

29 Wim J.J. Mertens, "Meubeltapisserieën in de Nederlanden en Frankrijk vanaf de Late Middeleeuwen tot 1900," PhD diss. (Leiden University, 2008). 
30 GAB, FAR, no. 368.

31 Ibid.

32 Ibid.

33 Ibid.

34 Jean Britz, Histoire de la jurisprudence et de la législation des Pays-Bas et des Principautés de Liège, de Bouillon et de Stavelot (Brussels: 1846), xi.

35 Aude Hendrick, "Des mots de circonstance: Les discours de rentrée de la haute magistrature belge au XIXe siècle," PhD diss. (USL Brussels, 2012), 274.

36 GAB, FAR, no. 368.

37 Jos Monballyu, ed., Filips Wielant verzameld werk I (Brussels: Paleis der Academiën, 1995), 7-27.

38 Egidius Strubbe, "Joos de Damhouder als criminalist," Tijdschrift voor Rechtsgeschiedenis 37 (1970): 1-65.

39 Philippe Godding, "Defacqz Eugène," Nouvelle biographie nationale, 6 (Brussels: Académie Royale de Belgique, 2001), 106-11.

40 Jean-Pierre Nandrin, "L'acte de fondation des nominations politiques de la magistrature: La Cour de cassation à l'aube de l'indépendance belge," Belgisch Tijdschrift voor Nieuwste Geschiedenis 2 (1998): 158.

41 GAB, FAR, no. 368.

42 Geerinck, "De Decoratie van het Justitiepaleis te Brussel," 304 . Vincent Vanhamme, Xavier Mellery: De ziel der dingen (Amsterdam: Van Gogh Museum, 2000), 60.

43 Robert Jacob, Images de la Justice: Essai sur l'iconographie judiciaire du Moyen Âge à l'âge classique (Paris: Léopard d'Or, 1994).

44 On the exegesis of historical imagery in courtrooms, see Hayaert and Garapon, Allégories de Justice, 93, 103-6.

45 "Of law and order" is my translation of the French "de la loi et du droit": “Le portrait de de Gerlache,' Journal des Tribunaux, 1896: 726.

46 L'Indépendance Belge, 17 March 1903, 2 and 12 May 1911, 3.

47 Ibid., 11 October 1910, 3.

48 Ibid., 2 October 1896, 1.

49 Ibid., 11 October 1910, 3.

50 Ibid., 12 May 1911, 3.

Erratum (pages 134 and 136)

Recent analysis of archival material showed that, in the end, the second tapestry inside the Cour de Cassation does not represent Joos de Damhouder, as originally debated, but Jean Wamèse (Wamesius, 1524-1590), a Liège-born law professor at Leuven University. 